\title{
Is Islamic Banking and Finance Doing Enough? Shaping the Sustainable and Socially Responsible Investment Community
}

\author{
Amiruddin Ahamat ${ }^{1}$ \\ ${ }^{1}$ Faculty of Technology Management and Technopreneurship, Universiti Teknikal Malaysia Melaka, Malaysia \\ Correspondence: Amiruddin Ahamat, Faculty of Technology Management and Technopreneurship, Universiti \\ Teknikal Malaysia Melaka (UTeM), Hang Tuah Jaya, 76100 Durian Tunggal, Melaka, Malaysia. Tel: \\ 606-283-3186. E-mail: amiruddin@utem.edu.my
}

Received: January 7, 2017

Accepted: January 19, 2017 Online Published: February 21, 2017

doi:10.5539/ass.v13n3p170

URL: https://doi.org/10.5539/ass.v13n3p170

\begin{abstract}
Islamic finance assets advanced at double-digit rates during the past decade, from about US\$200 billion in 2003 to an estimated US\$1.8 trillion at the end of 2013 (Ernst \& Young 2014; IFSB 2014; Wyman 2009). Hence, despite this growth, Islamic finance and its related products are still focused in the Gulf Cooperation Council (GCC) countries, and Malaysia, and represent less than 1 percent of global financial assets. While, Islamic banking and finance sector, should responsive to small medium enterprises mitigating liability of smallness and newness. The factors mitigating the inherent liabilities associated with new entrepreneurial startups were found to be institutional support. Institutional support was also found to be an important factor of success for new startups. The primary focus of this study is to examine the critical role of Islamic Banking and Finance, expanding and facilitating entrepreneurial opportunities. This study draws on triple bottom line concept (people, planet and profit), by developing standards equivalent to triple bottom line reporting for Islamic banking and financial institutions, and disseminating independent and objective research to relevant stakeholders. This includes examining the potential positive or negative social impact of Islamic Banking and Finance on the financially sustainable and responsible community.
\end{abstract}

Keywords: Islamic banking and finance, sustainable, responsible environment, triple bottom line

\section{Introduction}

Consistently, the Islamic banking concept has gained popularity worldwide attributing to the major opportunities it offers, such as the diversification of the investor base and its ability to lure and increase a country's investment (Osman 2012; Ahmad, 2008). This is visible from the significantly high compound annual growth rate recorded in the Islamic banking industry during the years of the global economic adversity between 2006 and 2009 (Reuters, 2010). The Islamic banking and finance sector can influence the future direction of the economy, and as such, may act as a motivator towards realising a prosperous future and sustainable development. Socially responsible investment in sectors such as renewable energy, or in environmentally/ socially sound endeavours, can make a more meaningful contribution to the economy than perhaps more traditional ventures (Setchell, 2015). Responsible investments are likely to bring a greater return to investors. Alertness among consumers about the role of sustainability is increasing, and social and environmental arguments are affecting decision-making. Nevertheless, 'green' businesses are more competitive and are likely to achieve greater financial results while simultaneously addressing the triple bottom line.

From the Middle East perspective, the potential in sustainable business and socially responsible investing is great. One of the principles of Islamic banking is to not invest in projects that are detrimental to society, which exhibits the extent to which Islamic finance contributes to a broader values-based social system. The Islamic principles that lead Islamic finance include the concept of humankind as trustees of nature. This instils a level of responsibility to safeguard society and environment, and demonstrates the potential for the region to seek these principles even further in a business situation. Taking these distinctions into account is the Islamic Reporting Initiative (IRI), which delves to promote the use of triple bottom line reporting as an instrument for business development and growth, in a context that is regulated with Islamic principles. Additionally, the favourable geography of the region prepares it with great renewable energy resources, such as solar power. This may serve as a major competitive advantage in the field of sustainable development, with consumers increasingly scrutinizing the social and environmental impact of organizations. 


\section{Methodology}

The primary objective of this study is to investigate the critical role of Islamic Banking and Finance, expanding and facilitating entrepreneurial opportunities. This study draws on triple bottom line concept (people, planet and profit), by establishing standards equivalent to triple bottom line reporting for Islamic banking and financial institutions, and disseminating independent and objective research to relevant stakeholders. This includes examining the potential positive or negative social impact of Islamic Banking and Finance on the financially sustainable and responsible community. This paper proposes for new business framework that promotes ethical leadership, employee well being, sustainable and socially responsibility community without sacrificing profitability, revenue growth, and other financial and performance indicators. This means shaping business frameworks integrating Islamic Finance and Banking sector on approaches that have a positive economic, social, and environmental impact, often referred to as the triple bottom line. The triple bottom line - or "People, Planet, Profit" (TBL) - encloses a definite set of moral values and criteria for measuring organizational (and societal) success and with it a need to institute triple bottom line assessment and reporting (Fry \& Slocum Jr, 2008). TBL is coined by John Elkington of "SustainAbility" (UK) in 1995. TBL is one of the main systems being used by businesses to examine the profits they are making through their corporate sustainability solutions. The Triple Bottom Line approach observes how one see beyond the traditional bottom line of business to the profits that one generates socially, environmentally, and economically.

Notwithstanding many similarities, the nature of the human and financial resources for social entrepreneurship contradicts in some key respects, primarily because of difficulties in resource mobilization (Austin, Stevenson, \& Wei-Skillern, 2006). Contrary, a commercial entrepreneur who often has the financial resources or incentives to recruit and retain talent, social entrepreneurs is rarely able to pay market rates for key hires (Oster, 1995). Small medium enterprises may be considered non-bankable and unqualified for formal loan because they lack of collateral to back their loan applications. This demonstrates the liability of smallness and newness of the enterprises in enacting new business opportunities. Yunus \& Jolis (2003) stated that the poor are not lack of talents thus should be given opportunity in terms of capital to be independent entrepreneurs. Hence, it is the right time for Islamic banking and finance sector is to offer sustainable micro-financing services or products to such communities. Microfinance is a supply of relatively small loans, savings and other basic financial services to the poor has made an impact in the lives of many over the years across the globe (Rahman, 2007). MFIs have developed from a humble beginning of village banks or cooperatives in Egypt in 1960s to a very structured institutions like Grameen Bank in Bangladesh, BancoSol in Bolivia, Unit Desa Bank Rakyat Indonesia and ACCION International in the United States and Latin America (Dusuki, 2008) and the opportunity for Islamic Banking and Finance sector is still wide and open. Furthermore, with the repayment rate of more than $90 \%$ the microfinance sector has been proven to be low risk and profitable business (Hassan et al, 2012).

Table 1. Triple Bottom Line (TBL) Framework in Socially Responsible Investment Community

\begin{tabular}{ll}
\hline Sustainable Issues & Broad Considerations \\
\hline $\begin{array}{l}\text { People } \\
\text { Social Sustainability }\end{array}$ & $\begin{array}{l}\text { Social equity and cohesion - shaping the well beings of individual and the community to } \\
\text { increase institutional-individual relationship (Islamic banking and finance sector and } \\
\text { community) }\end{array}$ \\
$\begin{array}{l}\text { Planet } \\
\text { Environmental Sustainability }\end{array}$ & $\begin{array}{l}\text { Responsible and sustainable community in natural resources exploitation } \\
\text { Profit }\end{array}$ \\
$\begin{array}{l}\text { Financial Sustainability and } \\
\text { Sustenance (Barokah) }\end{array}$ & $\begin{array}{l}\text { Sharing liability and risk } \\
\text { Spiritual Sustenance }\end{array}$ \\
\hline
\end{tabular}

The establishment of Grameen Bank by Prof. Muhammad Yunus, and known as bank for the poor is considered a replicable financing model to small medium enterprises that demonstrates lack of critical funding opportunities. The abstractly new and not well established small medium enterprises are presumably being considered as 'nonbankable' and not credit worthy due to the absent of physical assets; hence granting credits to them is 'very risky' (Hassan et al., 2012). As a result, most microfinance providers are dominated by NGOs (Brugnoni, 2010). Yunus (2003) has proven that the group lending system as per Grameen Bank model overcome this predicament and the poor are given the chance to provide 'social collateral' instead. Hence, Islamic Banking and Finance should be more innovative and socially responsible by offering 'social collateral' to the entrepreneurship community. Though, the risk is inevitable, the Islamic banking and finance sector may mitigate the risk through the peer monitoring, joint liability and eventually has effectively increase repayment rate, decrease adverse selection and significantly reducing cost (Brau \& Woller, 2004). In framing the theoretical foundation of this study, TBL 
evolves from two dimensions of the sustainable issues and broad considerations. This is summarized using the Table 1.

\section{Discussion}

\subsection{The Context of People}

The application of triple bottom line (TBL) to enable socially sustainable entrepreneurship community is significant in the sense that it drives broader consideration of people, planet and profit in the context of Islamic banking and finance sector. A triple bottom line institution takes steps to ensure that its operations aid the company's employees as well as the community in which it conducts business. In a TBL context, the development of human capital is shaped by social equity hence the well being of individual and the community (local or global) increases institutional-individual relationship. Islamic banking and finance managers of TBL entities are concerned, not just with providing adequate compensation and rewards to its workers, but strengthening the role of institutional-individual relationships by creating innovative, accessible and community friendly services and products to the community. The value and meaning for Islamic banking and finance is not only to seek positive ways to contribute to the community through activities, such as charitable contributions, education programs and equal opportunity employment yet incorporating this sector as one of the effort to enable the community.

To further understand the context of this discussion, this paper connects the case of Amanah Ikhtiar Malaysia (AIM). AIM is one of the microfinance institutions (MFI) in Malaysia. This institution has been operating for more than 20 years extending credits and micro insurance to the micro entrepreneurs. AIM relies on grants and loans from different local and international institutions (Ismail, 2001). This institution offers no interest charges and flexible against defaulters. This is in line with the teaching of the Holy Quran; 'If the debtor is in difficulty, grant him time till it is easy for him to repay. But if you remit it by the way of charity, that is best for you if you only knew.' (Note 1) On top of entrepreneurial support of micro credit, AIM offers training, business networking and matching activities. These efforts transform micro entrepreneurs ability to become economically sustainable. Since 31st January 2012, AIM products and services benefitted almost 297,790 participants with more than MYR 6 billion allocated to the community, with the repayment rate of 99.6\% (AIM, 2008). Apart from the financial impact on microfinance on the participants, Morduch in Saad and Duasa (2010) said that there is also a social dimension involved in the programme. There are views that governments may not be able to provide full public interests and are not capable of achieving developmental goals.

Hence, the key notion is to motivate commercial sector capacity in production of goods and services that in effect elicited the advancement of the economic development in the developed countries and fields of economic prosperity, employment and stable relative welfare of citizens (Salarzehi, Armesh \& Nikbin, 2010). This in return supports the social dimension and the improvement in community's health status, the children's education and increasing the overall life quality of the community. This is proven in the impact study conducted by AIM in 2005 and reported that $90 \%$ of the participants have successfully exit poverty after 4 borrowings and $74.9 \%$ (AIM, 2008). This signifies the critical role of Islamic banking and finance in offering more and innovative solutions to the entrepreneurship and the community.

The reports on Islamic Banking Opportunities Across Small and Medium Enterprises by International Financial Corporation, World Bank, which includes countries namely Iraq, Pakistan, Yemen, Kingdom of Saudi Arabia, Egypt, Lebanon, Morocco, Tunisia, and Jordan, reiterates several reasons for the lack of access to finance for small medium enterprises (SMEs) in these countries. The study demonstrates that, there is a potential gap of USD $\$ 8.63$ billion to USD\$13.20 billion for Islamic SME financing within un-served and underserved SMEs categories, with a reciprocal deposit potential of $\$ 9.71$ billion to $\$ 15.05$ billion across these countries. This is by reason of un-served and underserved SMEs ignoring the conventional banks, only owing to religious reasons. This potential is a "new to bank" funding opportunity, which is still unexplored, as banks and other financial institutions lack of sufficient strategic focus on this segment to offer Shariah-compliant products. This is the strategic role of Islamic Banking and Finance and to increase visibility in 'still untapped' markets. Islamic financial institutions have offered several financial instruments and products that comply with the Shariah and through such instruments, Islamic banking and financial institutions could also serve as the financial inter-mediation to SMEs, they also need to advance the human resources (confidence, skills, knowledge and information) among the clients at the same time to build local structures that help SMEs to grow progressively (Abdullah \& Hoetoro, 2011).

\subsection{Building Sustainable Environmental Life}

A TBL company evades any activities that harm the environment and looks for ways to lessen any negative 
impact its operations may have on the ecosystem. It manages its energy consumption and takes steps to reduce its carbon emissions. Many TBL companies go beyond these basic measures by utilising other means of sustainable development, such as using wind power. Many of these practices actually increase a company's profitability while contributing to the health of our planet. In Islam, human and environment interaction is led by the notion of the person as a vicegerent or steward of the earth (Jusoff \& Abu Samah, 2011). As vicegerents of Allah in earth, Muslims are accountable to Him to protect and preserve what $\mathrm{He}$ has entrusted them with (amanah) (Farook, 2007). Farook further posits that destruction of or adversity to the physical environment, if it is considered harmful to the interests of the individual or the society at large, is prohibited in Islam. An Islamic way of a sustainable environmental life entails living in "peace and harmony (salam)" at individual, social as well as ecological levels (Jusoff \& Abu Samah, 2011). It is essential for every individual to ensure that their actions have minimal environmental impacts. While Islamic Banking and Finance sector itself does not have direct environmental consequences, projects supported by this sector may have significant environmental impacts. Hence, actors within this sector should be responsible to ensure that such harmful investments are avoided and actively promotes, opportunities that is sustainable and responsible to the environment and community.

Farook (2007) suggests the social impact based investment notion. This according to Farook, due to the special financial strengths (because of their diversification capabilities and economies of scale), they are able to devote in industries that produce social, cultural or religious development in line with Islamic ideals. This is much relevant to be implemented by Islamic Banking and Finance institutions in countries such as Saudi Arabia, UAE, Qatar and Malaysia. Hypothetically, opportunities in socially, culturally and religiously driven areas, could be identified as social impact based investments hence may employ social entrepreneurship as an instrument to enable the SMEs. Therefore, relevant Islamic institutions (such as Islamic banks, Islamic microfinance institutions, and / or Business Development Services) should provide a vast space of accessibility to SME owners and their resources to ensure capacity for exchange in line with Islamic criterion of mutual interdependence among related agents (Abdullah \& Hoetoro, 2011). It will be truly challenging to incorporate social entrepreneurship within Islamic Banking and Finance as this sector is mostly driven by profit. Balancing profit with social motives will never be easy as business are more motivated towards achieving financial returns and making shareholders happy. To ensure shareholders to be happy nevertheless, banking and financial institutions including Islamic banking and finance sector, tries to push profit as their main business agenda.

\subsection{The Role of Social Entrepreneurship}

Discovering and creating business opportunities for new venture creation are paramount in shaping entrepreneurial actions and the intent to develop potential business opportunities (Ahamat \& Chong, 2014). The role of social entrepreneurship in the context of Islamic banking and finance is mainly caused by its essential signals to drive social change. Harding (2006) suggests that the significant role of social entrepreneurship is that it contributes to an economy by providing a substitute business model for enterprises to trade commercially in an environmentally and socially sustainable way, and it also provides an alternative delivery system for public services. Rolland (2006) posited that the uniqueness of this company is that they view the primary purpose of the company in creating jobs and value to the communities, and not to shareholders' profitability.

Here, the motives will be driven both namely financial returns and social returns. Abdullah \& Hoetoro (2011), posit that profitability is still an objective, but it is not the only goal, and profits are re-invested in the mission ( $d a^{\prime}$ wah or Islamic propagation) rather than simply being distributed to shareholders as determined in the Holy Qur'an Surah al-Hashr: 7, saying that: "What Allah has bestowed on His Apostle (and taken away) from the people of the townships -belongs to Allah- to His Apostle and to kindred and orphans, the needy and the wayfarer; in order that it may not (merely) make a circuit between the wealthy among you......". Nevertheless, the incorporation of social entrepreneurship to enable the socially responsible investment community is much supported to build sustainable and responsible investment community.

\subsection{The Concept of Barakah (Spiritual Sustenance)}

Previously, profitability was considered the only important factor in an opportunity seeking behaviour, yet businesses today have had to expand their thinking in this regard. In Islam, there is no separation between entrepreneurial activities and religion. Islam has its own entrepreneurship characteristic and guiding principles based on al-Quran and al-Hadith to guide entrepreneurship operation (Oukil, 2013). By morality of the human nature, the person must firstly be a Muslim, then the entrepreneur hence he has the responsibility to perform ibadah and be a khalifah (Faizal, Ridhwan and Kalsom, 2013). Muslim entrepreneur should search for Allah"s blessings above all other factors. Muslim entrepreneurs perform entrepreneurial activities not solely for profit, 
but above all, to fulfil the fardu kifayah Vargas-Hernández, Noruzi, and Sariolghalam, 2010).

The paper posited that belief system that is embedded and practiced (such as religion) is a vital element of an individual in their journey of opportunity creation. Hence, there are massive challenges and difficulties for entrepreneurs in organizing their limited resources to achieve their business aims. Research demonstrates that socio-economic crises result in more people inclining to religion and spirituality (Smith \& Danton, 2005). The paper suggests that the unique systems of meaning, action, or beliefs emerging from the human processing deeply rooted in the Islamic concept of tasawwur (conception), which advocates the concept of spiritual sustenance. Islamic tasawwur demonstrates entrepreneurship as one of the best forms of livelihood or occupation (Sa'ari \& Abdul Hamid, 2011). Al-Quran manifests this encouragement towards Muslims clearly through a summons like "seek, using all resources available on earth and open up opportunities for the same cause" (Note 2). Yusuf al-Qaradawi (2001) indicates that the philosophy of Islamic entrepreneurship (adding the emphasis of spiritual sustenance) is driven on economic philosophy itself, where businesses or trades are based on Rabbani (divine) and divinity traits. Al-Quran itself asserts the spirit and principles of freedom, justice, and morality in every mode of entrepreneurial activity.

The principles, conditions, and guidelines that have been set aim to ensure the survival of the business (Ahmad, 1995) and to achieve barakah (blessings) from Allah the Almighty. This is written in the holy book of Al-Quran: "Worship is done by people of strong faith who are not distracted by business or trade from quoting and remembrance of Allah; establish regular prayers and practice regular charity; they fear the hereafter." (Surah An-Nur: 37). The idea of business as Ibadah or worship emulates a guiding principle of the social belief system ingrained in the opportunity creation process. While, for the Muslim entrepreneurs, opportunities are interpreted as rezeki (sustenance), yet sustenance is a responsibility more than a reward. Muslims consider that trustworthy and good deeds will result in barakah from Allah. This may result in ease in daily activities, a happy life and a lot of blessings in this life and the hereafter. Barakah or blessing is one important element that establishes the view of spiritual sustenance.

Barakah is the Arabic word which demonstrates grave; in particular, it is a spiritual gift or for protection from God Almighty, Allah. In Christian religion there is a word berakhah, which explains appeal or excellence award from the Lord. Incidentally, the word Baraka used in the French language is identical with the word luck (fate). Hence, barakah advances the feeling or a sense of self-efficacy, a belief in dealing with businesses or commercial transactions. This is interpreted in the book of the Holy Quran where the word barakah is among the blessings that Allah says in Surah Al-A'raf verse 96, which means, "If the State of the people believe and fear surely we will bestow on them blessings from heaven and the earth." In the context of Islamic Banking and Finance, it is imperative that the actors in this sector to filter their investments for compliance with Islamic laws and principles develop a clear policy outlining their method of filtering investments and the depth of their filtering or screening (Farook, 2007).

\section{Conclusion}

To answer the key question in this study, is Islamic Banking and Finance doing enough, this paper suggests more innovative efforts to integrate TBL in shaping sustainable and responsible investment. The proposed triple bottom line framework helps unleash the critical people, planet and profit in building more sustainable and responsible investment community. The role of Islamic Banking and Finance institutions are eminent. Taking this notion into account is the Islamic Reporting Initiative IRI, which seeks to promote the use of triple bottom line reporting as a mechanism for business development and growth, in a context that is aligned with Islamic values and principles.

However, one main issue with the triple bottom line is that the three separate contexts cannot easily be integrated. It is challenging to examine the planet and people accounts in the same terms as profits - that is, in monetary terms. The full cost of an open burning in several countries leading to haze and schools closures, for example, is probably immeasurable in monetary terms, as is the opportunity cost of absences of children and teachers from schools, or the health cost of the communities in far remote areas without adequate health facilities. Like most subjective communication efforts or intangible benefits, your socially and responsibly driven activities can be difficult to measure. However, the Islamic Reporting Initiative (IRI) is essential to enable businesses to report and measure their social impact.

Future empirical study is useful to draw better conclusions on this interesting study. Hence, applying employing interpretive inquiry approach to the research subject could operationalize this. While, interpretive analysis aims to shape how people experience the world, the ways they interact together and the settings in which these interactions take place. This includes the interpretation of meaningful human expressions such as written, verbal 
and/or physical (Ahamat \& Chong, 2015). Two key notions involved, namely human activity and social life. Smith (1992) contends that human actions are those assertions people make based on reasons, intentions and motivations while the idea of social must be added because the meanings attributed to human actions, both by the actors and the interpreters are determined by and can only be understood within a social meaning in this context all the stakeholders involved in Islamic Banking and Finance.

\section{Acknowledgements}

This research and manuscript publication is made possible by the publication fee awarded to Dr. Amiruddin bin Ahamat of Faculty of Technology Management and Technopreneurship, Universiti Teknikal Malaysia Melaka (UTeM). The author is grateful to Universiti Teknikal Malaysia Melaka (UTeM) for the financial support.

\section{References}

Abdullah, M. A., \& Hoetoro, A. (2011). Social Entrepreneurship as an Instrument to Empowering Small and Medium Enterprises: An Islamic Perspective. International Journal of Management Business Research, $1(1), 35-46$.

Ahamat, A., \& Chong, S. C. (2014). Assessment of The Factors Influencing Entrepreneurs on The Biotechnology Business Venture. Proceedings of the 24th International Business Information Management Association Conference - Crafting Global Competitive Economies: 2020 Vision Strategic Planning and Smart Implementation, pp. 2171-2177.

Ahamat, A., \& Chong, S. C. (2015). Multi-Methodological Approaches in Qualitative Entrepreneurship Research. International Business Management, 9(4), 601-612. http://dx.doi.org/10.3923/ibm.2015.601.612

Ahmad, W. (2008). Islamic Banking in the United Kingdom: Opportunities and Challenges. Kingston Business School: London.

Amanah Ikhtiar Malaysia (AIM) Annual Report 2008.

Austin, J., Stevenson, H. \& Wei-Skillern, J. (2006). Social and Commercial Entrepreneurship: Same, Different, or Both. Entrepreneurship Theory \& Practice. http://dx.doi.org/10.1111/j.1540-6520.2006.00107.x

Brau, J. C., \& Woller, G. M. (2004). Microfinance: A Complete Review of Existing Literature. Journal of Entrepreneurial Finance and Business Ventures, 9(1), 1-26.

Brugnoni, A. (2010). Managing Microfinance. Islamic Banking and Finance, 8(1), $26-29$.

Dusuki, A. W. D. (2008). Banking for the poor: the role of Islamic banking in microfinance initiatives. Humanomics, 24(1).

Faizal, P. R. M., Ridhwan, A. A. M., \& Kalsom, A. W. (2013). The Entrepreneurs Characteristic from al-Quran and al-Hadis. International Journal of Trade, Economics and Finance, 4(4). https://doi.org/10.7763/IJTEF.2013.V4.284

Farook, S. (2007). On Corporate Social Responsibility of Islamic Financial Institutions. Islamic Economic Studies, 15(1), July.

Fry, L. W., \& Slocum JR, J. W. (2008). Maximizing the Triple Bottom Line through Spiritual Leaderships Organizational Dynamics, 37(1), 86-96. https://doi.org/10.1016/j.orgdyn.2007.11.004

Harding, R. (2006). Social Entrepreneurship Monitor. United Kingdom. London Business School.

Hassan, S., Abdul Rahman, R., Abu Bakar, N., \& Lahsasna, A. (2012). Towards Triple Bottom Lines Microfinance Institutions (MFIs) - A Case Study of Amanah Ikhtiar Malaysia (AIM), a paper presented at University of Sharjah conference on excellence Business, United Arab Emirates.

Iqbal, Z., \& Mirakhor, A. (2007). Qard Hasan Microfinance (QMHF). New Horizon, Apr-June, 18 -20.

Ismail, R. (2001). Economic and Social Impact of Amanah Ikhtiar Malaysia (AIM) Scheme: A Case Study in Kedah and Terengganu. Humanomics, 17(1), 141-155. https://doi.org/10.1108/eb018866

Jusoff, K., \& Abu Samah, S. A. (2011). Environmental Sustainability: What Islam Propagates. World Applied Science Journal, 12(Special Issue on Creating a Knowledge Based Society), 46-53.

Osman, A. (2012). Islamic Finance and Takaful: Capturing the Africa Opportunity. Retrieved from http://www.islamicbankingafrica.megaevents.net

Oster, S. M. (1995). Strategic management for non-profit organizations: Theory and cases. New York: Oxford University Press. 
Oukil, M. S. (2013). Entrepreneurship and Entrepreneurs in an Islamic Context. Journal of Islamic and Human Advanced Research, 3(3), 111-131.

Rahman, A. R. A. (2007). Islamic Microfinance: A missing component in Islamic banking. Kyoto Bulletin of Islamic Area Studies, 1(2).

Reuters. (2010). Reuters. Retrieved from http://uk.reuters.com/article/idUKTRE6IE2JD

Rolland, S. (2006). Mondragon Corporation Cooperatives, People Working Together. UW-L Journal of Undergraduate Research $I X$.

Saad, N., \& Duasa, J. (2010). Determinants of Economic Performance of Micro-Credit Clients and Prospects for Islamic Microfinance in Malaysia. ISRA International Journal of Islamic Finance, 2(1), 113-130.

Saari, C. Z., \& Abdul Hamid, S. (2011). Reconstructing Entrepreneur s Development Based on al- Quran and al-Hadith. International Journal of business and Social Science, 2(19), 110- 116.

Salarzehi, H., Armesh, H., \& Nikbin, D. (2010). Waqf as a Social Entrepreneurship Model in Islam. International Journal of Business and Management, 5(7). https://doi.org/10.5539/ijbm.v5n7p179

Salwana Hassan, Rashidah Abdul Rahman, Nordin Abu Bakar, Ahcene Lahsasna. May, (2012). Towards Triple Bottom Lines Microfinance Institutions (MFIs)- A Case Study of Amanah Ikhtiar Malaysia (AIM). Paper Presented in the International Conference on Excellence in Business, Sharjah, UAE.

Setchell, M. (April 20, 2015). How to anchor sustainability into your business. CSR in Middle East.

Smith, C., \& Denton, M. L. (2005). Soul searching: The religious and spiritual lives of American teenagers. Oxford, UK: Oxford University Press. https://doi.org/10.1093/019518095X.001.0001

Smith, J. K. (1992). Interpretive inquiry: A practical and moral activity. Theory Pract. 31, 100-106. https://doi.org/10.1080/00405849209543530

Vargas-Hernández, J. G., Noruzi, M. R., \& Sariolghalam, N. (2010). An exploration of the affects of Islamic Culture on Entrepreneurial Behaviours in Muslim Countries. Asian Social Science, 6(5), 120-127. https://doi.org/10.5539/ass.v6n5p120

Yunus, M., \& Jolis, A. (2003). Banker to the poor: Micro-lending and the battle against world poverty: Public Affairs.

\section{Notes}

Note 1. Surah Al Baqarah (The Heifer) verse 280.

Note 2. In Surah al-Ja"siah (45): 12-13, al-Hijr (15): 19-22, al-An,,am (6): 141, al-Najm (53): 39, al-Nur (24): 37, al-Jumu,,ah (62): 9 dan al-Tawbah (9): 24.

\section{Copyrights}

Copyright for this article is retained by the author(s), with first publication rights granted to the journal.

This is an open-access article distributed under the terms and conditions of the Creative Commons Attribution license (http://creativecommons.org/licenses/by/4.0/). 